\section{Катерина МІЛІЦИНА}

\section{Антропоцентризм міжнародного авторського права: значення та наслідки для об'єктів, створених за допомогою штучного інтелекту та штучним інтелектом безпосередньо}

\begin{abstract}
Стаття зосереджена на антропоцентризмі як концепції, яка складає основу міжнародного авторського права. Вона також аналізує вплив даної концепції на національні законодавства та ідентифікує виклики та ризики, які має антропоцентризм для об'єктів, створених за допомогою штучного інтелекту та штучним інтелектом безпосередньо.

Ключові слова: міжнародне авторське право, антропоцентризм, критерій оригінальності, штучний інтелект.

The article draws attention to anthropocentrism as the ground upon which the International Copyright Law builds. It analyses the impact of this concept on national legislations and identifies challenges and risks which anthropocentric approach entails to AI-assisted and AI-created objects.

Keywords: International Copyright Law, anthropocentrism, originality criteria, artificial intelligence.
\end{abstract}

Постановка проблеми. В момент зародження та впродовж подальшого розвитку міжнародне авторське право мало на меті, перш за все, створити систему, за якої суспільство могло б користуватися результатами творчості авторів, які в свою чергу отримували б за це певну винагороду та гарантії захисту їх прав. Міжнародне авторське право тримає цей баланс між публічними і приватними інтересами по теперішній час. Незважаючи на це, саме питання особи автора залишилося без прямої відповіді міжнародного авторського права. Можливо, це пов'язано із тим, що такий стрімкий розвиток технологій було важко передбачити, а отже, дана проблема не була на порядку денному, оскільки, за замовчуванням, авторство ототожнювалося з людиною, яка створила твір. Питання ототожнення автора $з$ людською особистістю постало в той момент, коли технології перестали бути виключно засобом, натомість трансформувавшись у невід'ємну частину процесу створення або ж набувши здатність генерації чогось нового самостійно, без людського втручання. У зв'язку із вищесказаним виникла нагальна потреба у з'ясуванні змісту поняття «автор», що дасть змогу проаналізувати, чи достатнім є сучасний стан міжнародного авторського права для того, щоб підтримати та стимулювати розвиток штучного інтелекту.

Стан дослідження проблеми. Фундаментальними в сфері розкриття проявів антропоцентризму в міжнародному авторському праві є наукові доробки Сема Рікетсона [3]. Також питання штучного інтелекту та авторського права є предметом досліджень Яні Іхалайнен, Каліна Хрістова [10], Джеймса Вагнера [14] тощо.

Метою даної статті є дослідити прояви антропоцентризму як засадничої концепції міжнародного авторського права та, відповідно, з' ясувати наслідки, які це може мати по відношенню до об'єктів, створених за допомогою штучного інтелекту та штучним інтелектом безпосередньо.

Антропоцентризм міжнародного авторського права. Бернська конвенція про охорону літературних і художніх творів у статті 1 говорить, що країни, до яких застосовується дійсна Конвенція, утворюють Союз для охорони прав авторів на ї літературні i художні твори (виділено автором) [1]. Таким чином, Конвенція закріплює права авторів, однак не торкається питання визначення автора, що пов' язано із суттєвою різницею національних підходів 3 даного питання [2, с. 11]. На думку професора Сема Рікетсона, відсутність визначення «автора» у Конвенції пов'язано із тим, що між дер-

УДК 341.9, 347.78:004.8

() К. Міліцина, 2019
МІЛІЦИНА Катерина Максимівна

здобувач кафедри Міжнародного приватного права

Інституту міжнародних відносин Київського національного університету імені Тараса Шевченка 
жавами існувала певна «домовленість» із значення цього терміну [3, с. 8]. В Конвенції не встановлено і вимоги щодо того, що твори, яким надається охорона, мають бути результатом творчості автора. Будь-які пропозиції внести такі зміни були відхилені на підставі того, що такий зміст вже закладено в термін «літературні і художні твори». 3 цього випливають два наступні висновки: 1) автором має бути людина; 2) людина має зробити свій творчий внесок [3, с. 10]. В свою чергу авторське право також стоїть на позиції того, що лише людина є джерелом творчості і може створити твори, які є оригінальними в розумінні авторського права [4, с. 384]. Окрім цього, висновок про антропоцентричність міжнародного авторського права можна зробити, враховуючи наступні норми Бернської конвенції про охорону літературних і художніх творів: 1) строк охорони прав за Конвенцією становить увесь час життя автора i n'ятдесят років після його смерті, що в свою чергу є властивістю живої істоти; 2) наявність моральних прав (дане питання було предметом дискусій між державами континентальної та англо-американської правових систем), необхідність закріплення яких обгрунтовувалася саме $з$ посиланням на потреби автора-людини; 3) кінематографічні твори є єдиним випадком в Конвенції, який допускає, що автором може бути не лише людина; 4) перелік творів, який наразі наведений в ст. 2 Конвенції видозмінювався в ході перегляду Конвенції, однак внесення кожної нової позиції до переліку обгрунтовувалося тим, що створення даного об'єкта вимагає творчих зусиль [3, с. 11]. Таким чином, незважаючи на те, що Конвенція не містить положень, які прямо зазначають, що автором є людина, висновок про те, що антропоцентризм є концепцією, яка червоною ниткою проходить крізь ії зміст, можна зробити із передумов розробки Конвенції та низки їі норм.

Вплив на національні законодавства. Все це мало свій вплив на національні законодавства держав, які, зважаючи на доволі широкі формулювання Конвенції, мали певну дискрецію при закріпленні даних норм та їх тлумаченні. По-перше, законодавства багатьох держав прямо визначають, що автором є людина. Зокрема, ст. 1 Закону України «Про авторське право і суміжні права» встановлює, що автором є фізична особа, яка своєю творчою працею створила твір [5]. Найбільш прогресивним з точки зору адаптації до технологічного розвитку є законодавство Великобританії, де існує поняття творів, створених за допомогою комп'ютерних технологій (прим. - переклад автора) (англ. - computer-generated work) [6]. Автором в такому разі вважається особа, яка здійснила дії, необхідні для створення певного твору. Однак, якщо ми говоримо про штучний інтелект, який набуває все більшої «автономності» від людини, то формулювання цієї норми не є відповіддю тим викликам, які виникають у зв' язку із даним явищем, оскільки норма все ж таки говорить про технології як засіб. По-друге, визначити таку особу у випадку застосування штучного інтелекту теж буде важко, оскільки потрібно буде оцінити вклад кожної особи, яка була причетна до процесу створення об'єкта, та визначити найважливіший з них, що наразі представляється більше суб'єктивною категорією. Що ж до США, то тут автором теж є людина. Виключенням 3 цього правила є доктрина «шоrk for hire», за якою автором вважається роботодавець або особа, яка замовила створення твору [7, с. 126]. Однак США продовжують відстоювати антропоцентризм власного авторського права. Показовим є рішення у справі «Naruto v. Slater», в якому судом було встановлено, що тварини не можуть отримати охорону за авторським правом, оскільки законодавством в сфері авторського права не передбачено, що тварини можуть подати позов про порушення їх авторських прав [8]. Провівши паралель із українським законодавством, можна сказати, що аргументація судом власного рішення засновується на відсутності у тварин процесуальної правоздатності та дієздатності. Не дивно, що навіть на рівні керівних принципів, які в своїй діяльності використовує Бюро авторського права США, закріплено, що Бюро реєструватиме оригінальні твори за умови, якщо автором є людина [9, гл.300, с. 4]. Бюро не реєструватиме твори, створені машиною або в результаті механічного процесу за відсутності будь-якого творчого вкладу людини [9, гл. 300, с. 7]. Таким чином, США радше зроблять вибір на користь розширення тлумачення існуючих норм авторського права щодо об'єктів, створених за допомогою штучного інтелекту та штучним інтелектом безпосередньо, аніж підуть на зміни правового режиму та відмовляться від концепції, де автор ототожнюється 3 людиною, оскільки це спричинить більше питань, ніж відповідей [10, с. 441].

Окрім вимоги щодо особи автора, перешкодою для отримання охорони за авторським правом об'єктами, які створені за допомогою штучного інтелекту та штучним інтелектом безпосередньо, є вимога щодо творчого вкладу. Вище вже зазначалося про те, що даний критерій охороноздатності творів не закріплений прямо в Бернській конвенції про охорону літературних і художніх творів, а радше випливає із іï змісту. В свою чергу він зазвичай прямо закріплений на рівні національних законодавств і розтлумачений судами. Розгалуженою щодо даного питання є практика Суду ЄС. У справі C-145/10 - Painer було встановлено, що ключову роль у визнанні прав інтелектуальної власності за автором відіграє те, чи є твір відображенням авторської особистості. Це проявляється у можливості прийняття автором вільних та креативних рішень [11]. У справі C-403/08 - Football Association 
Premier League and Others було зазначено, що творчий процес полягає у наявності творчої (креативної) свободи [12], а у справі C-5/08 - Infopaq International було встановлено, що оригінальність має відображати інтелектуальну творчість автора [13]. Існують великі сумніви, що об'єкти, створені за допомогою штучного інтелекту і штучним інтелектом безпосередньо, відповідають даним вимогам, що буде розглянуто нижче.

Штучний інтелект - ступінь втручання людини. На початку штучний інтелект дійсно використовувався переважно як засіб. Сьогодні ж він здатний самостійно створювати нові об'єкти. Таким чином, умовно, для цілей цієї статті, можна виділити наступні види: об'єкти, створені за допомогою штучного інтелекту; об'єкти, створені штучним інтелектом. Серед об'єктів, створених за допомогою штучного інтелекту, можна виокремити ще декілька видів залежно від ступеню втручання людини у процес створення: 1) людина може продовжувати використовувати штучний інтелект як засіб; 2) «співпраця» штучного інтелекту і людини; 3) людина тренує штучний інтелект (обирає патерни, задає характеристики тощо) для подальшої генерації штучним інтелектом нових об'єктів; 4) мінімальний рівень втручання людини.

Значення та наслідки антропоцентризму для об'єктів, створених за допомогою штучного інтелекту та штучним інтелектом безпосередньо. Головними перешкодами з точки зору авторського права для об'єктів, створених за допомогою штучного інтелекту і штучним інтелектом безпосередньо, є наступні: 1) творчий вклад (оригінальність) як критерій охороноздатності; 2) визначення, що автором є людина.

Критерій творчого вкладу. Аргументи на користь того, що штучний інтелект потенційно може відповідати критерію творчого вкладу, можуть бути наступними. По-перше, об'єкти, створені за допомогою штучного інтелекту та штучним інтелектом безпосередньо, часто справляють враження таких, що створені людиною. По-друге, штучний інтелект продовжує розвиватися від середовища, тому навіть розробник певної нейромережі не може однозначно передбачити результати їі подальшої роботи. По-третє, продовжуючи розвиватися, нейромережа потенційно може перевершити здібності людини в тій сфері, в якій вона функціонує. Однак потрібно визнати, що контраргументи наразі є більш вагомими. Незважаючи на все зазначене, штучний інтелект, принаймні зараз, залишається обмеженим тими характеристиками та алгоритмами, які першочергово були задані розробником чи розробниками. Вихід за такі характеристики та аналогія набутого досвіду в інших сферах все ще залишаються предметом досліджень. Це означає відсутність свободи творчості та вільного вибору. Окрім цього, варто зазначити про існування контраргументу «китайської кімнати», який полягає в тому, що нейромережа виконує певні дії, наслідком чого є отримання певного результату, але при цьому вона не має здатності усвідомлювати їх значення, на відміну від людини. Це можна порівняти із перекладом за допомогою онлайн-перекладача [14, с. 531].

Встановлення особи автора. Навіть якщо припустити відповідність об'єктів, створених за допомогою штучного інтелекту і штучним інтелектом безпосередньо, критерію творчого вкладу, виникає низка запитань стосовно того, хто має вважатися автором. Наразі існують наступні можливі варіанти: розробник програми; особа, яка вводила дані, необхідні для тренування нейронної мережі; особа, яка задала певні критерії для створення такого об'єкта; співавторство згаданих осіб або деяких 3 них; ніхто - об'єкт одразу переходить у вільний доступ.

Висновки і перспективи. Наразі об'єкти, створені за допомогою штучного інтелекту або штучним інтелектом безпосередньо, не відповідають вимогам, які висуваються як міжнародним авторським правом, так і національним авторським правом держав. Це створює всі передумови для того, щоб такі об'єкти одразу переходили у вільний доступ. В той самий час за умови, якщо в процесі створення об'єкта бере участь одна або більше осіб, об'єкт може отримати охорону. Автором буде вважатись людина, однак хто саме - залишається відкритим питанням.

Враховуючи те, що такий стан справ не може забезпечити стимулів для подальшого розвитку штучного інтелекту та захищеність інтересів суспільства, авторське право буде вимушене пройти етап змін, як на міжнародному рівні, так і на національному. Варіанти, як це має відбуватися вже висуваються. Серед них, зокрема, є такі: розширення тлумачення існуючих норм; створення нового правового режиму шляхом поєднання норм авторського права та права промислової власності; надання правосуб'єктності роботам тощо. Дані пропозиції будуть предметом подальших досліджень автора. 
1. Бернська конвенція про охорону літературних і художніх творів. Паризький Акт від 24 липня 1971 року змінений 2 жовтня 1979 року. URL: https:/ /zakon.rada.gov.ua/laws/show/995_051

2. Guide to the Berne Convention for the Protection of Literary and Artistic Works (Paris Act 1971). URL: https://www.wipo.int/edocs/pubdocs/en/copyright/615/wipo_pub_615.pdf

3. Ricketson S. The 1992 Horace S. Manges Lecture - People or Machines: The Berne Convention and the Changing Concept of Authorship. - Columbia-VLA Journal of Law \& the Arts. 1991. № 16:1. pp. 1-37.

4. Bonadio E., Lucchi N. Non-Conventional Copyright: Do New and Atypical Works Deserve Protection? - Cheltenham, UK: Edward Elgar Publishing, 2018. - 528 p.

5. Закон України «Про авторське право і суміжні права». URL: https://zakon.rada.gov.ua/laws/ show/3792-12

6. Copyright, Designs and Patents Act 1988. URL: https://www.legislation.gov.uk/ukpga/1988/48/ section/9

7. Copyright Law of the United States and Related Laws Contained in Title 17 of the United States Code. URL: https://www.copyright.gov/title17/title17.pdf

8. Naruto v. Slater, No. 16-15469 (9th Cir. 2018). URL: http://cdn.ca9.uscourts.gov/datastore/ opinions/2018/04/23/16-15469.pdf

9. Compendium of U.S. Copyright Office Practices. Third Edition. URL: https://www.copyright. gov/comp3/docs/compendium.pdf

10. Hristov K. Artificial Intelligence and the Copyright Dilemma. - IDEA: The IP Law Review. 2016. № 57. pp. 431-454.

11. Judgment of the Court (Third Chamber) of 1 December 2011. - Eva-Maria Painer v Standard VerlagsGmbH and Others. C-145/10. ECLI:EU:C:2011:798. URL: http://curia.europa.eu/juris/liste. jsf?\&num=C-145/10

12. Judgment of the Court (Grand Chamber) of 4 October 2011. - Football Association Premier League Ltd and Others v QC Leisure and Others and Karen Murphy v Media Protection Services Ltd. Joined cases C-403/08 and C-429/08. C-403/08. ECLI:EU:C:2011:631. URL: http://curia.europa.eu/juris/liste. jsf?num $=\mathrm{C}-403 / 08 \&$ language $=\mathrm{en}$

13. Judgment of the Court (Fourth Chamber) of 16 July 2009. - Infopaq International A/S v Danske Dagblades Forening. C-5/08. ECLI:EU:C:2009:465. URL: http://curia.europa.eu/juris/liste.jsf?num=c-5/08

14. Wagner J. Rise of the Artificial Intelligence Author. - The Advocate. 2017. № 75:4. - pp. 527-533.

\section{Anthropocentrism of the International Copyright Law: Significance and Consequences for AI-assisted and AI-created objects}

\section{Summary}

The International Copyright Law does not explicitly state that it is anthropocentrism that underpins its essence. However, meticulous analysis of its provisions leads us to such conclusion. Presumably the states, which participated in the drawing up of the Berne Convention for the Protection of Literary and Artistic Works, were agreed that only human beings could be regarded as authors. The Convention also alludes to the criterion of 'originality' or 'intellectual creation' as the major requirement for copyright protection. Given that the creative ability is generally attributed to humans, this criterion supports the idea of anthropocentric copyright. Although there may be considerable differences between legislative approaches, these basic provisions have been implemented by the member states. The interpretation of these milestone principles may vary by state but under any circumstances they constitute an obstacle for AI-assisted and AI-created objects.

Nowadays, artificial intelligence is capable of producing objects which will exceed human performance. After the launch, AI-based programme continues improving, making it impossible to predict the result of its further work even for the programmer. In any such case, though, AI is limited by algorithms, features, memory, power etc. This casts doubt on its ability to make 'free and creative choices' reflecting its 'personal touch'. The 'Chinese-room argument' is another ground for challenging AI-creativity. Even if we omit originality criterion, we will face another complicated question - issue of authorship. Bearing in mind the human author requirement, the AI-created objects, which exclude any human interference, are most likely to enter the public domain. The AI-assisted objects present a different category. The modern technological advancement and exponential growth were hardly foreseen in the past. That is why the International Copyright Law and national legislations have incorporated approaches which treat technologies as a tool. 
Therefore, AI-assisted objects can potentially qualify for copyright protection. Still, who is the author? The list can include the following variants: a programmer; an investor; a person who has trained neural network; a user; joint authorship or collective work; nobody etc.

The nature of technologies has changed. They are no longer mere tools. Not many years ago, the creation process was exclusively subject to manifestation of creativity. Now it is rather the question of production capacity. Using artificial intelligence, companies can create all possible variants within certain settings. In a worst-case scenario any future works will be considered as infringing their rights. Probably, that is the reason why copyright still stays silent on AI-assisted and AI-created objects, leaving us without the answer whether they are copyrightable and who is the author and depriving the parties concerned of the incentives to develop the industry. If the world is not to become a victim of its scientific success, it may be in its best interest to depart from the milestones of the Copyright Law. The countries already put forward their own initiatives. Particularly, in the not too distant future we may either observe reinterpretation of the existing provisions, witness convergence between copyright and industrial property law with respect to AI-assisted and AI-created works, or discover a new legal regime. 